Elïbieta Roszko-Wójtowicz

Uniwersytet Lódzki

Maria M. Grzelak

Uniwersytet Lódzki

\title{
Wielowymiarowe ujęcie zróżnicowania poziomu jakości życia w województwach w Polsce
}

\author{
A MULTIVARIATE APPROACH TO THE \\ DIFFERENTIATION IN THE LEVEL OF QUALITY OF \\ LIFE IN POLAND'S VOIVODSHIPS
}

Jakości życia wyrażana jest nie tylko poprzez konsumpcję dóbr materialnych $i$ ushug, ale przede wszystkim przez możliwość zaspokojenia potrzeb zwiazanych $n p$. ze stanem środowiska naturalnego, rodzajem $i$ postaciq więzi międzyludzkich, godnościq $i$ poszanowaniem praw człowieka, a także ilościq $i$ jakościq wolnego czasu oraz samorealizacja. Rozległy wachlarz problemów i zjawisk pozostajacych $w$ bezpośredniej relacji z jakościa życia, sprawa, że jej pomiar jest zagadnieniem trudnym $i$ cieszacym się niestabnacym zainteresowaniem badaczy. Celem artykutu jest wielocechowa ocena jakości życia $w$ województwach $w$ Polsce z uwzględnieniem szczegółowego omówienia pomiarów jednowymiarowych $i$ zmian $w$ czasie. $W$ wyniku przeprowadzonych analiz wykazano, że wyodrębniony zestaw zmiennych charakteryzuje sie relatywnq stabilnościq $w$ czasie. Ranking województw w roku 2016 nie odbiegat znaczaco od rankingu przygotowanego dla roku 2010. Daje to podstawę aby sqdzić, że wybrane zmienne można uznać, za kluczowych reprezentantów poszczególnych kategorii opisujacych jakość życia.

Słowa kluczowe: jakość życia, porządkowanie liniowe, zróżnicowanie, metoda współczynników korelacji cząstkowej

\section{Wprowadzenie}

Jakość życia definiowana jest jako stopień zaspokojenia potrzeb materialnych oraz niematerialnych. Jest poziomem satysfakcji człowieka z ogółu swojej egzystencji. Należy do najważniejszych zagadnień współczesnej nauki tym samym jest jedną $\mathrm{z}$ podstawowych kategorii badawczych statystyki społecznej. Określa poziom spełniania standardów oraz realizacji wartości: biologicznych, psychicznych, duchowych, socjalnych, politycznych, kulturowych oraz ekonomicznych. Pojęcie to stosowane jest w polityce społecznej, psychologii, pedagogice, medycynie, filozofii, ekonomii oraz socjologii. Jakość życia łączy się z oszacowaniem stopnia usatysfakcjonowania potrzeb ludzkich, który jest oznaką zmian społecznych i gospodarczych występujących w kraju.

Jakość życia jest jednym z najpopularniejszych tematów nauk i kategorii życia dotyczących ludzkiej egzystencji. Ponieważ ma ona charakter wielowymiarowy współczesna nauka nie stworzyła dotychczas uniwersalnej koncepcji tego określenia. Od najdawniejszych czasów starano się zgłębić misterium szczęścia, poszukując czynników 
koniecznych do uzyskania satysfakcji, zadowolenia z życia oraz świadomości dobrostanu. Nawet jeśli nie używamy tego pojęcia, jakość życia jest dla każdego człowieka pojęciem fundamentalnym, a większość wysiłków kierujemy na poprawę lub zachowanie poziomu jakości życia ${ }^{1}$. Kategoria jakość życia jest współcześnie nie tylko aspektem rozważań teoretycznych, ale również rodzajem postrzegania i oceny sytuacji społecznej. Przyjęcie pojęcia jakości życia w świadomości społecznej jest kluczowym powodem przemawiającym za uczynieniem $\mathrm{z}$ niego dziedziny badań. Ze względu na wielowymiarowe ujęcie jakości życia, wynikające m.in. $\mathrm{z}$ zainteresowania tym zagadnieniem przedstawicieli różnych dziedzin nauki, pomiar tej kategorii jest zadaniem trudnym. Warto jednak podkreślić, że pełny obraz jakości życia danej zbiorowości uzyskać można tylko przy podejściu holistycznym, wielowymiarowym i interdyscyplinarnym ${ }^{2}$.

W tym kontekście głównym celem artykułu jest wielocechowa ocena jakości życia w województwach $\mathrm{w}$ Polsce $\mathrm{z}$ uwzględnieniem szczegółowego omówienia pomiarów jednowymiarowych i zmian w czasie. Celem pośrednim było dokonanie pomiaru jakości życia w możliwie jak najwęższym zakresie. Dlatego też na potrzeby opisu jakości życia ograniczono się do wyodrębnienia dziewięciu głównych kategorii (domen). Każdej z nich został przypisany tylko jeden reprezentant, uznany za kluczowego. Postępowanie badawcze zostało zrealizowane dla dwóch punktów czasowych, był to rok 2010 oraz 2016. Zbiór zmiennych wejściowych powstał w oparciu o Bank Danych Lokalnych oraz statystyki policyjne.

Uzyskanie porównywalności wyników w czasie było dla Autorów kluczowe. Dlatego też wszystkie analizy zostały przeprowadzone na podstawie danych statystyki publicznej. Dodatkowo, w badaniu wykorzystano tylko mierniki mające charakter zagregowany. W związku z tym należy mieć na uwadze, że wyznaczony w artykule miernik syntetyczny, w pewnym sensie określa potencjalny poziom jakości życia $\mathrm{w}$ poszczególnych jednostkach terytorialnych.

\section{Jakość życia - wybrane zagadnienia}

Zainteresowanie różnych dyscyplin naukowych, między innymi: ekonomii, socjologii, pedagogiki, psychologii oraz medycyny, badaniami nad jakością życia społeczeństw, skutkuje interdyscyplinarnością oraz komplementarnością w ujmowaniu niniejszego zjawiska. Szczególnie warto przywołać tutaj osiagnięcia Organizacji Narodów Zjednoczonych. Przygotowana przez komisję ekspertów w 1954 roku definicja podaje, że „Pojęcie poziomu życia obejmuje całoksztalt rzeczywistych warunków życia ludzi oraz stopień ich materialnego i kulturalnego zaspokojenia potrzeb poprzez strumień dóbr i ustug odplatnych, a także pochodzqcych z funduszy społecznych" ${ }^{3}$. Jest to jedno z kluczowych określeń wykorzystanych $\mathrm{w}$ dalszej operacjonalizacji jakości

\footnotetext{
${ }^{1}$ J. Owsiński, T. Trachalski, Współczesne Problemy Zarzqdzania. Pomiar jakości życia. Uwagi na marginesie pewnego rankingu, Instytut Badań Systemowych PAN, Warszawa 2008, s. 61-67.

2 A. Sompolska-Rzechuła, Jakość życia jako kategoria ekonomiczna, Folia Pomeranae Universitatis Technologiae Stetinensis, Oeconomica, nr 301 (71), 2013.

${ }^{3}$ Nations Unies, Rapport sur la definition et evaluation des niveaux de vie du point de vue international (Report on the identification and assessment of living standards as an economic indicator internationally), New York 1954, s. 5.
} 
życia. Właśnie ta definicja stanowiła podstawę dla rozwoju wielu kolejnych określeń tego pojęcia ${ }^{4}$.

Początkowo termin - jakość życia - utożsamiany był jedynie ze stanem posiadania danej jednostki. Przyjmowano, że więcej dóbr materialnych jakie posiadał człowiek, przekłada się na wyższy standard życia, co wprost było utożsamiane z lepszą jakością życia. Na przestrzeni lat, przekonano się jednak, że wzrost majątku nie musi oznaczać wzrostu jakości życia. Doprowadziło to do poszerzenie definicji o dodatkowy „poziom”. Jakość życia nie znaczyła już tylko „mieć ” ale też „mieć i być”. Ludzie nie spełniają się jedynie poprzez powiększanie swojego majątku ale mają też potrzeby emocjonalne oraz duchowe, które choć są trudne do zmierzenia, dla większości osób są determinantami jakość życia i kształtują ich poczucie spełnienia oraz szczęścia. Luszniewicz ${ }^{5}$ (1982) wyróżnił siedem podstawowych rodzajów potrzeb: bezpieczeństwo, wyżywienie, ochrona zdrowia, warunki mieszkaniowe, komunikacja i transport, edukacja i kultura oraz ochrona środowiska.

Tym co wyróżnia pojęcie jakości życia od kategorii tradycyjnych takich, jak konsumpcja oraz warunki bytu jest rozległy wachlarz problemów i zjawisk zawierających się w jej zakresie. Jest ona wyrażana nie tylko poprzez konsumpcję dóbr materialnych i usług, ale przede wszystkim przez możliwość zaspokojenia potrzeb związanych np. ze stanem środowiska naturalnego, rodzajem i postacią więzi międzyludzkich, godnością i poszanowaniem praw człowieka, a także ilością i jakością wolnego czasu oraz samorealizacją ${ }^{6}$. Nie ma jednak jednoznacznej definicji opisującej jakość życia. Stanowi ona przedmiot badań nauk teoretycznych takich jak: socjologia, ekonomia i psychologia ${ }^{7}$. W ujęciu psychologicznym jakość życia bywa utożsamiana z sensem życia oraz ocenami wartościującymi życie i szczęście człowieka. Właśnie na gruncie psychologii powstało pojęcie jakości życia, pozwalające na zachowanie odpowiednich proporcji między subiektywną a obiektywną stroną życia. Tym samym, skierowano przedmiot badań naukowych na rozterki moralne i światopoglądowe człowieka, postawę wobec życia i systemy wartości, którymi się kieruje. Jakość życia w psychologii rozumiana jest najczęściej jako subiektywne doznania oraz doświadczenia, które są wynikiem codziennego życia. Te natomiast są składowymi poczucia zadowolenia z życia, doświadczenia oraz psychicznego dobrobytu.

Pojęcie to obecne jest również w badaniach socjologicznych, gdzie najistotniejsze są kwestie związane z potrzebami socjalnymi oraz materialnymi. Według socjologów występuje wiele ich odmian, lecz wspólną myślą przewodnią jest odzwierciedlenie sposobów oraz stopnia zaspokojenia potrzeb społeczeństwa. Pośród wielu definicji cechą charakterystyczną jest istota rozróżniania przez socjologów dwóch życiowych orientacji „mieć” i „być”. Podczas badania jakości życia należy skupić się na próbie odpowiedzi na

\footnotetext{
${ }^{4}$ Por. m.in.: A. Luszniewicz, Statystyka spoleczna. Podstawowe problemy i metody, PWE, Warszawa 1982; Cz. Bywalec, L. Rudnicki, Podstawy teorii $i$ metodyki badań konsumpcji, Akademia Ekonomiczna w Krakowie, Kraków 1992; J. Piasny, Poziom i jakość życia ludności oraz źródła i mierniki ich określania, Ruch Prawniczy, Ekonomiczny i Socjologiczny, Rok LV, Zeszyt 2, 1993; T. Słaby, Poziom i jakość życia [w:] T. Panek, A. Szulc (red.), Statystyka Społeczna. Wybrane zagadnienia, SGH w Warszawie, Oficyna Wydawnicza, Warszawa 2007;

${ }^{5}$ A. Luszniewicz, Statystyka spoleczna. Podstawowe problemy i metody, PWE, Warszawa 1982.

${ }^{6}$ J. Rutkowski, Jakość Życia-Koncepcja i projekt badania, ZBSE, Warszawa 1987, s. 7-10.

${ }^{7}$ E. Jankowska, Pojęcie i narzędzia pomiaru jakości życia, Toruńskie Studia Międzynarodowe, nr 1(4), Toruń 2011, s. 34-37.
} 
pytanie ,jakim być?”. Pragnienie istnienia oraz pragnienie posiadania, które określają naturę ludzką to odmienne rodzaje odniesienia do siebie i świata, ukazujące całość ludzkich przemyśleń, odczuć i działań. Analiza motywacji pragnienia życia oraz posiadania znacząco wpływa na określenie niskiej bądź wysokiej jakości życia. W ujęciu socjologicznym pojęcie jakości życia nawiązuje do zaspokajania potrzeb, takich jak potrzeba bezpieczeństwa, samorealizacji, czy uznania społecznego.

Ekonomia klasyfikuje jakość życia jako stopień zaspokojenia potrzeb materialnych, społecznych oraz duchowych, a także stan społecznej satysfakcji stanowiący rezultat postrzegania przez jednostkę warunków życia w sposób całościowy. Wszystkie z omówionych ujęć łączy jeden wspólny mianownik - potrzeba, którą najłatwiej zdefiniować jako odczucie braku czegoś. Odczuwany jest przy tym stan napięcia, który jest silnie związany z fizjologią organizmu, miejscem jednostki w społeczeństwie oraz indywidualnym doświadczeniem. Podstawowym modelem, który opisuje życiowe potrzeby jest tzw. hierarchia potrzeb Maslowa ${ }^{8}$. U jej podstaw znajdują się potrzeby fizjologiczne (biologiczne), po zaspokojeniu których, jednostka dąży do spełnienia potrzeb bezpieczeństwa i kolejno potrzeb przynależności. Po zaspokojeniu potrzeb niższego rzędu, jednostka pragnie spełniać te należące do wyższego poziomu. Są to potrzeby szacunku oraz samorealizacji. Maslow zakłada, iż potrzeby niższego rzędu są bardziej ograniczone od tych wyższego rzędu, ale jednocześnie bardziej wyraźne. Model ten pokazuje, jak zaspokojenie poszczególnych potrzeb może wpływać na odczucie dobrobytu jednostek.

Jakość życia można „zmierzyć” za pomocą wskaźników społecznych jak i ekonomicznych'. Odpowiedni miernik jakości życia powinien spełniać m. in. następujące warunki:

$>$ powinien opierać się na danych aktualnych, których gromadzenie nie jest kosztowne i pracochłonne ${ }^{10}$;

$>$ powinien być dobierany $\mathrm{w}$ taki sposób, aby istniała możliwość porównania analizowanych jednostek pod kątem procesów rozwojowych;

> powinien w głównej mierze odzwierciedlać efekty uzyskiwane przez instytucje oraz organizacje $\mathrm{z}$ tytułu prowadzonej działalności, natomiast w mniejszym stopniu nakłady wykorzystane na osiagnięcie owych efektów;

$>$ powinna istnieć możliwość przeprowadzenia ponownych, porównywalnych pomiarów wartości wskaźników w celu zaobserwowania zmian w czasie;

> wskaźnik powinien mieć charakter normatywny, czyli jego zmiana powinna być postrzegana przez społeczeństwo za zjawisko pozytywne lub negatywne;

> powinien opisywać skutki realizowanej polityki gospodarczej, a także społecznej, ograniczając jednocześnie działania mające na celu jedynie poprawe $\mathrm{w}$ zakresie badanego zjawiska, opisanego przy pomocy danego wskaźnika.

\footnotetext{
${ }^{8}$ A. Miler-Zawodniak, Teorie potrzeb jako współczesne teorie motywacji, Obronność - Zeszyty Naukowe Wydziału Zarządzania i Dowodzenia Akademii Obrony Narodowej, nr 4, 2012, s. 101-116.

${ }^{9}$ J. Kordos, Metodologia i wykorzystanie wskaźników społecznych, Wiadomości Statystyczne, 1990, nr 12.

${ }^{10}$ B. Sztaur-Jaworska, Diagnoza i diagnozowanie w polityce społecznej, [w:] G. Firlit-Fesnak, M. SzylkoSkoczny (red.), Polityka społeczna, PWN, Warszawa 2009.
} 


\section{Źródla danych statystycznych w pomiarze jakości życia}

Ze statystycznego punktu widzenia poziom szczęścia, poziom satysfakcji człowieka z ogółu swojej egzystencji nie należy do najłatwiejszych, gdyż dla każdej osoby oznacza on co innego. Dobór zmiennych adekwatnych do potrzeb badania jest zadaniem trudnym. Naukowcy prowadzą liczne dyskusje na temat najrzetelniejszego sposobu pomiaru szczęścia. W ostatnich latach stał się nim wskaźnik jakości życia ludności, którego zadaniem jest odzwierciedlenie odczuwanego przez ludzi zadowolenia łączącego w sobie zarówno cechy obiektywne jak i subiektywne. W obliczu globalnych dyskusji na temat jakości życia określono międzynarodowe standardy jej pomiaru ${ }^{11}$. Zespół zadaniowy działający w ramach Europejskiego Systemu Statystycznego (ESS) przedstawił wytyczne dotyczące koncepcji badania jakości życia, w tym również definicje wybranych zmiennych charakteryzujących jakość życia. Zmienne te reprezentują umownie przyjęte różnorakie obszary tematyczne (domeny). Sposób pomiaru jakości życia w niniejszym badaniu opiera się na koncepcji przedstawionej przez Główny Urząd Statystyczny, która bazuje na międzynarodowych zaleceniach zespołu EES. Publikowane przez GUS zagregowane dane statystyczne opisujące jakość życia to wyniki badań ankietowych, danych spisowych, sprawozdawczości statystycznej oraz wyniki reprezentacyjnego badania gospodarstw domowych ludności. W koncepcji pomiaru jakości życia, przyjętej w artykule, uwzględniono obszary tematyczne, które prezentuje rys. 1. Koncepcja pomiaru jakości życia opracowana przez GUS stanowi podstawę dla postępowania badawczego opisanego w artykule. Przy czym, ostateczny dobór zmiennych to propozycja autorska.

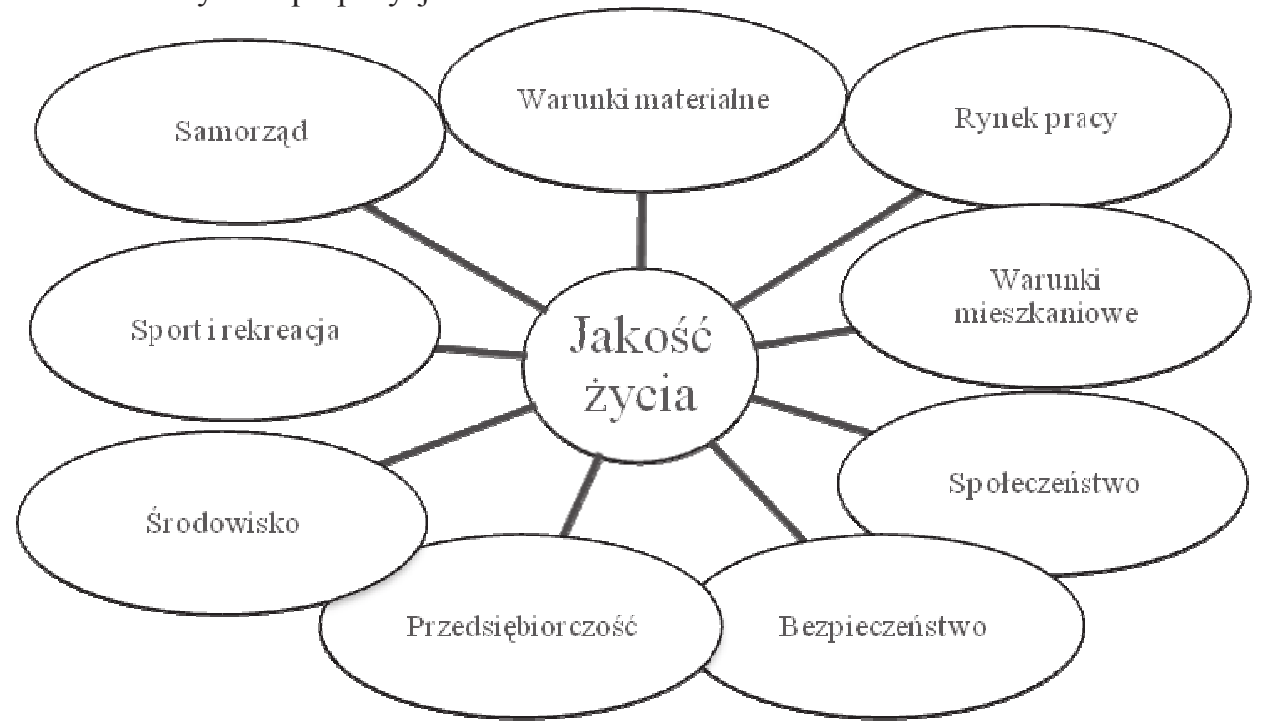

Rysunek 1. Domeny/dziedziny jakości życia uwzględnione w konstrukcji miernika syntetycznego Źródło: opracowanie własne

11 A. Szukiełojć-Bieńkuńska, T. Walczak, Statystyczny pomiar postępu społeczno-gospodarczego w zmieniajacym się świecie, Wiadomości statystyczne, nr 7/8 (602/603) 2011, s. 23-24. 
Celem prowadzonej analizy statystycznej jest dokonanie oceny i pomiaru jakości życia w polskich województwach w roku 2010 oraz 2016. Porównanie różnych aspektów jakości życia pozwoli w konsekwencji na dokonanie klasyfikacji województw w Polsce w oparciu o skonstruowany miernik syntetyczny. Ocena jakości życia w prowadzonym badaniu została przeprowadzona na podstawie wartości dziewięciu różnych wskaźników, z których każdy jest kluczowym reprezentantem tylko jednej dziedziny. Dzięki podejściu, w którym poszczególne domeny jakości życia zostały zmierzone za pomocą indywidualnych zmiennych, w postępowaniu badawczym nie było konieczne wyznaczanie agregatów cząstkowych.

Prezentowane zestawienie tabelaryczne zawiera informacje o poszczególnych reprezentantach przypisanych do uprzednio wyodrębnionych dziedzin jakości życia. W tabeli został również określony kierunek wpływu poszczególnych zmiennych diagnostycznych na jakość życia. Spośród dziewięciu cech diagnostycznych, dwie z nich to destymulanty. Stymulanty to zmienne, dla których pożądanymi są wartości jak najwyższe, w przeciwieństwie do destymulant, dla których sytuacja korzystna związana jest $\mathrm{z}$ niskimi wartościami ${ }^{12}$.

Tabela 1. Zmienne diagnostyczne wraz z przypisanymi dziedzinami jakości życia oraz kierunkiem wpływu na zmienną syntetyczną

\begin{tabular}{|c|c|c|c|}
\hline Kategoria & Zmienna & $\begin{array}{c}\text { Oznaczenie } \\
\text { zmiennej }\end{array}$ & $\begin{array}{l}\text { Kierunek } \\
\text { wplywu }\end{array}$ \\
\hline Przedsiębiorczość & $\begin{array}{l}\text { Liczba podmiotów gospodarczych w } \\
\text { przeliczeniu na } 1000 \text { mieszkańców }\end{array}$ & $\mathrm{X} 1$ & Stymulanta \\
\hline Rynek pracy & $\begin{array}{c}\text { Udział liczby bezrobotnych w liczbie osób w } \\
\text { wieku produkcyjnym (\%) }\end{array}$ & $\mathrm{X} 2$ & Destymulanta \\
\hline $\begin{array}{c}\text { Warunki } \\
\text { mieszkaniowe }\end{array}$ & 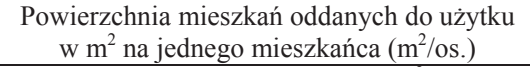 & X3 & Stymulanta \\
\hline Społeczeństwo & Gęstość zaludnienia $\left(\mathrm{os} . / \mathrm{km}^{2}\right)$ & $\mathrm{X} 4$ & Stymulanta \\
\hline Bezpieczeństwo & $\begin{array}{c}\text { Wskaźnik wykrywalności przestępstw } \\
\text { kryminalnych (\%) }\end{array}$ & $\mathrm{X} 5$ & Stymulanta \\
\hline Środowisko & Emisja zanieczyszczeń pyłkowych na $1 \mathrm{~km}^{2}$ & X6 & Destymulanta \\
\hline Sport i rekreacja & $\begin{array}{l}\text { Udział parków, zieleńców i terenów zieleni } \\
\text { osiedlowej w powierzchni ogółem }\end{array}$ & $\mathrm{X} 7$ & Stymulanta \\
\hline Samorząd & $\begin{array}{c}\text { Nakłady inwestycyjne na jednego mieszkańca } \\
\text { w zł }\end{array}$ & X 8 & Stymulanta \\
\hline Warunki materialne & Średnie wynagrodzenie brutto w zł & X 9 & Stymulanta \\
\hline
\end{tabular}

Źródło: opracowanie własne na podstawie Banku Danych Lokalnych - www.stat.gov.pl oraz statystyk policyjnych.

W województwach w Polsce ujawniają się znaczące różnice w zakresie jakości życia. Szczególnie jest to widoczne w relacji do wartości indywidualnych wskaźników społecznych oraz gospodarczych. Wartości tych wskaźników, niejednokrotnie, mogą mieć istotny wpływ na decyzje dotyczące wyboru miejsca zamieszkania, lokowania siedziby przedsiębiorstwa, czy nawet wyboru ścieżki edukacyjnej. Ocena jednowymiarowa, choć bardzo ważna i wartościowa, może prowadzić do błędnych wniosków. Dlatego też wnikliwa i szczegółowa analiza rozkładu zbiorowości ze

12 I. Kurzawa, A. Łuczak, F. Wysocki, Zastosowanie metod taksonomicznych $i$ ekonometrycznych $w$ wielowymiarowej analizie poziomu życia mieszkańców powiatów w Polsce, [w:] Prace naukowe Uniwersytetu Ekonomicznego we Wrocławiu, Taksonomia 28. Klasyfikacja i analiza danych - teoria i zastosowania, Wyd. Uniwersytetu Ekonomicznego we Wrocławiu, Wrocław 2017, s. 130. 
względu na poszczególne zmienne została wsparta wielowymiarowym ujęciem jakości życia. W tym celu w artykule została podjęta próba konstrukcji miernika syntetycznego w oparciu o zestaw dziewięciu zmiennych diagnostycznych. Wyższa wartość wskaźnika zapisana przy konkretnym obiekcie będzie oznaczała, że województwo oferuje bardziej korzystne warunki dla życia i rozwoju. Tabela 2 przedstawia wybrane miary statystyki opisowej zmiennych diagnostycznych w 2010 oraz 2016 roku, uwzględnione w budowie wskaźnika jakości życia oraz mające na celu ukazanie występowania wspomnianych różnic.

Tabela 2. Podstawowe miary statystyki opisowej

\begin{tabular}{|c|c|c|c|c|c|c|c|c|}
\hline Rok & $\bar{x}$ & $\mathbf{M}_{\mathrm{e}}$ & $\mathbf{S}_{\mathbf{x}}$ & $\mathbf{V}_{\mathrm{s}}$ & $\mathbf{K}$ & $\mathbf{A}_{\mathbf{s}}$ & MIN & MAX \\
\hline & \multicolumn{8}{|c|}{ Liczba zarejestrowanych podmiotów gospodarczych w przeliczeniu na 1000 mieszkańców } \\
\hline 2010 & 97,58 & 97,4 & 17,3 & 0,18 & $-0,76$ & 0,34 & $\begin{array}{l}71,72 \\
\text { Podkarpackie }\end{array}$ & $\begin{array}{l}129,3 \\
\text { Mazowieckie }\end{array}$ \\
\hline \multirow[t]{2}{*}{2016} & 104,86 & 101,7 & 19,1 & 0,18 & $-0,44$ & 0,55 & $\begin{array}{l}78,84 \\
\text { Podkarpackie }\end{array}$ & $\begin{array}{l}146,85 \\
\text { Mazowieckie }\end{array}$ \\
\hline & \multicolumn{8}{|c|}{ Udział liczby bezrobotnych w liczbie osób w wieku produkcyjnym (\%) } \\
\hline 2010 & 8,36 & 8,2 & 1,6 & 0,19 & $-1,08$ & 0,19 & $\begin{array}{l}6,00 \\
\text { Śląskie }\end{array}$ & $\begin{array}{l}11,14 \\
\text { Warmińsko- } \\
\text { mazurskie }\end{array}$ \\
\hline 2016 & 5,93 & 5,9 & 1,4 & 0,23 & $-1,27$ & 0,11 & $\begin{array}{l}3,6 \\
\text { Wielkopolskie }\end{array}$ & $\begin{array}{l}8,06 \\
\text { Warmińsko- } \\
\text { mazurskie }\end{array}$ \\
\hline & \multicolumn{8}{|c|}{ Powierzchnia mieszkań oddanych do użytku w m² na jednego mieszkańca (m²/os.) } \\
\hline 2010 & 0,35 & 0,3 & 0,1 & 0,28 & 0,20 & 0,73 & $\begin{array}{l}0,19 \\
\text { Świętokrzyskie }\end{array}$ & $\begin{array}{l}0,56 \\
\text { Mazowieckie }\end{array}$ \\
\hline 2016 & 0,37 & 0,3 & 0,1 & 0,25 & $-0,98$ & 0,37 & $\begin{array}{l}0,22 \\
\text { Opolskie }\end{array}$ & $\begin{array}{l}0,55 \\
\text { Mazowieckie }\end{array}$ \\
\hline & \multicolumn{8}{|c|}{ Gęstość zaludnienia $\left(\mathrm{os} . / \mathrm{km}^{2}\right)$} \\
\hline 2010 & 129,87 & 116,2 & 74,4 & 0,57 & 7,15 & 2,43 & $\begin{array}{l}59,62 \\
\text { Podlaskie }\end{array}$ & $\begin{array}{l}375,81 \\
\text { Śląskie }\end{array}$ \\
\hline 2016 & 129,17 & 116,3 & 73,7 & 0,57 & 6,68 & 2,35 & $\begin{array}{l}58,78 \\
\text { Podlaskie }\end{array}$ & $\begin{array}{l}369,67 \\
\text { Śląskie }\end{array}$ \\
\hline & \multicolumn{8}{|c|}{ Wskaźnik wykrywalności przestępstw kryminalnych (\%) } \\
\hline 2010 & 56,58 & 57,9 & 4,8 & 0,08 & $-0,91$ & $-0,46$ & $\begin{array}{l}47,09 \\
\text { Mazowieckie }\end{array}$ & $\begin{array}{l}63,4 \\
\text { Lubuskie }\end{array}$ \\
\hline 2016 & 56,90 & 58,2 & 5,1 & 0,09 & 1,15 & $-1,25$ & $\begin{array}{l}43,88 \% \\
\text { Mazowieckie }\end{array}$ & $\begin{array}{l}63,23 \% \\
\text { Świętokrzyskie }\end{array}$ \\
\hline & \multicolumn{8}{|c|}{ Emisja zanieczyszczeń pyłowych na $1 \mathrm{~km}^{2}$} \\
\hline 2010 & 0,23 & 0,2 & 0,2 & 1,01 & 12,38 & 3,33 & $\begin{array}{l}0,05 \\
\text { Warmińsko- } \\
\text { mazurskie }\end{array}$ & $\begin{array}{l}1,08 \\
\text { Śląskie }\end{array}$ \\
\hline 2016 & 0,14 & 0,1 & 0,16 & 1,12 & 13,90 & 3,62 & $\begin{array}{l}0,03 \\
\text { Warmińsko- } \\
\text { mazurskie }\end{array}$ & $\begin{array}{l}0,74 \\
\text { Śląskie }\end{array}$ \\
\hline & \multicolumn{8}{|c|}{ Udział parków, zieleńców i terenów zieleni osiedlowej w powierzchni ogółem (\%) } \\
\hline 2010 & 0,20 & 0,2 & 0,16 & 0,78 & 10,91 & 3,06 & $\begin{array}{l}0,06 \\
\text { Podlaskie }\end{array}$ & $\begin{array}{l}0,76 \\
\text { Śląskie }\end{array}$ \\
\hline
\end{tabular}




\begin{tabular}{|l|l|l|l|l|l|l|l|l|}
\hline 2016 & 0,21 & 0,2 & 0,16 & 0,77 & 10,53 & 2,99 & $\begin{array}{l}0,06 \\
\text { Podlaskie }\end{array}$ & $\begin{array}{l}0,77 \\
\text { Śląskie }\end{array}$ \\
\hline \multicolumn{7}{|c|}{ Nakłady inwestycyjne na jednego mieszkańca (zł) } \\
\hline 2010 & 5367,88 & 5157,0 & 1095,1 & 0,20 & 1,94 & 1,31 & $\begin{array}{l}3799 \\
\text { Lubelskie }\end{array}$ & $\begin{array}{l}8244 \\
\text { Mazowieckie }\end{array}$ \\
\hline 2016 & 5812,88 & 5501,5 & 1816,7 & 0,31 & 1,26 & 1,07 & $\begin{array}{l}3505 \\
\text { Świętokrzyskie }\end{array}$ & $\begin{array}{l}10533 \\
\text { Mazowieckie }\end{array}$ \\
\hline 2010 & 3181,44 & 3109,9 & 339,48 & 0,11 & 6,20 & 2,26 & $\begin{array}{l}2877,43 \\
\text { Podkarpackie }\end{array}$ & $\begin{array}{l}4279,55 \\
\text { Mazowieckie }\end{array}$ \\
\hline 2016 & 3993,79 & 3909,6 & 396,96 & 0,10 & 5,18 & 2,05 & $\begin{array}{l}3619,16 \\
\text { Warmińsko- } \\
\text { mazurskie }\end{array}$ & $\begin{array}{l}5240,86 \\
\text { Mazowieckie }\end{array}$ \\
\hline
\end{tabular}

Źródło: opracowanie własne na podstawie Banku Danych Lokalnych - www.stat.gov.pl oraz statystyk policyjnych.

$\bar{x}$ - średnia arytmetyczna, $\mathrm{M}_{\mathrm{e}}$ - mediana, $\mathrm{S}_{\mathrm{x}}$ - odchylenie standardowe, $\mathrm{V}_{\mathrm{S}}$ - współczynnik zmienności, $\mathrm{K}$ kurtoza, $A_{S}$ - współczynnik asymetrii, Min - minimalna wartość zmiennej, Max - maksymalna wartość zmiennej.

Liczba podmiotów gospodarczych może świadczyć o potencjalnej liczbie miejsc pracy ${ }^{13}$. Większa ilość tych podmiotów gwarantuje większą atrakcyjność województwa, gdyż przyczynia się ona do aktywizacji bezrobotnych, a tym samym mniejszego bezrobocia w społeczności. Ilość zarejestrowanych podmiotów na 1000 mieszkańców w województwach waha się między blisko 79 podmiotami w województwie podkarpackim a $147 \mathrm{w}$ województwie mazowieckim, które pod względem możliwości znalezienia stanowiska pracy jest najkorzystniejsze. Niemałe znaczenia ma fakt, iż jest to województwo, w którym znajduje się Warszawa. Średnia liczba podmiotów na 1000 mieszkańców we wszystkich województwach wynosi 104,86. W połowie z nich liczba ta jest równa lub większa od 101,72. Są to województwa: opolskie, śląskie, małopolskie, lubuskie, wielkopolskie, pomorskie, dolnośląskie, zachodniopomorskie i mazowieckie. Najmniej podmiotów gospodarczych w przeliczeniu na 1000 mieszkańców jest zarejestrowanych w województwach: podkarpackim, lubelskim i podlaskim. Największy wzrost w porównaniu z rokiem 2010 zarejestrowano w województwie mazowieckim, wyniósł on 13,58\%. Najmniejsze zmiany nastąpiły w województwie zachodniopomorskim (o $1,26 \%$ ).

Kolejna ze zmiennych stanowi odbicie sytuacji panującej na rynku mieszkaniowym. Powierzchnia mieszkań oddanych do użytku $\mathrm{w} \mathrm{m}^{2}$ na jednego mieszkańca świadczy o atrakcyjności danego województwa. Dodatkowo, może być ważnym czynnikiem kształtującym poziom napływu nowych mieszkańców do danego województwa $^{14}$. Województwa, w których oddawana jest do użytku większa ilość (a tym samym większa powierzchnia ogółem) mieszkań mogą uchodzić za korzystniejsze pod kątem migracji, gdyż mogą zwiększać komfort psychiczny osób migrujących. Decydenci pewniej podejmą decyzję o zmianie miejsca pobytu lub zamieszkania, będąc

13 W. Pryjmak, O. Gołubnyk, Zarzqdzanie migracja ludności poprzez wplyw na czynniki społecznogospodarcze, ,Zeszyty Naukowe WSOWL, nr 4(162), 2011, s. 361.

${ }^{14}$ A. Mantaj, A. Ostromęcki, D. Zając, Czynniki ksztaltujące migracje ludności w gminach wiejskich Polski Wschodniej, Wiadomości Statystyczne, nr 11(678), 2017, s. 74-85. 
świadomym o dogodnych warunkach mieszkaniowych w miejscu docelowym. W 2016 roku oddano do użytku średnio $0,37 \mathrm{~m}^{2}$ powierzchni mieszkań na jednego mieszkańca. Blisko tej wartości utrzymuje się województwo zachodniopomorskie oraz podkarpackie. W połowie spośród wszystkich województw przeciętna wartość powierzchni wyniosła $0,34 \mathrm{~m}^{2}$ lub więcej. Największą wartość zanotowano w województwie mazowieckim, bowiem na jednego mieszkańca przypadło $0,55 \mathrm{~m}^{2}$. Najmniejszą natomiast $\mathrm{w}$ województwie opolskim - tam w przeliczeniu na jednego mieszkańca oddano do użytku $0,22 \mathrm{~m}^{2}$. W porównaniu z rokiem 2010 - największą dynamikę wzrostu wykazało województwo podlaskie, w którym wzrost wyniósł 9,54\%.

Między rozwojem społeczno - gospodarczym a zaludnieniem występuje silna zależność. Zmiany w zaludnieniu mogą stać się nie tylko przyczyną, ale także skutkiem zróżnicowania procesów rozwojowych. Gęstość zaludnienia generalnie stanowi potwierdzenie atrakcyjności województwa, jest stymulantą jakości życia. W ślad za gęstością zaludnienia powinien iść szerszy dostęp do infrastruktury, szersze perspektyw dla rozwoju zawodowego oraz bogatsza oferta kulturalno-rozrywkowa. Wysoka gęstość zaludnienia sprzyja jej dalszemu zwiększeniu, a mniejsza - dalszemu zmniejszaniu ${ }^{15}$. Najwyższą gęstość zaludnienia w 2016 roku odnotowano w województwie śląskim blisko 370 osób na $\mathrm{km}^{2}$. Najmniejszą natomiast w województwie podlaskim - niespełna 59 osób na $\mathrm{km}^{2}$. Gesstość zaludnienia we wszystkich województwach wynosi średnio 129,55 osoby na $\mathrm{km}^{2}$. W połowie województw wartość ta wyniosła 116,36 i więcej. Są to województwa: wielkopolskie, podkarpackie, pomorskie, łódzkie, dolnośląskie, mazowieckie, małopolskie i śląskie. W ujęciu dynamicznym - w porównaniu do roku 2010 tylko w czterech województwach zaobserwowano wzrost gęstości zaludnienia. Są to województwa: małopolskie, mazowieckie, pomorskie oraz wielkopolskie. Wśród nich największy wzrost wystapił $\mathrm{w}$ województwie mazowieckim i wynosił $1,88 \%$. W pozostałych województwach nastąpił spadek, największy w województwie opolskim (o $2,38 \%$ ). Jedynie w województwie podkarpackim gęstość zaludnienia prawie nie uległa zmianie.

Poziom bezpieczeństwa może być jednym z czynników wpływających na jakość życia. Zapewnienie bezpieczeństwa należy do obowiązków policji. Warto pamiętać, iż jest ono jednym $\mathrm{Z}$ najważniejszych problemów zarówno na poziomie międzynarodowym, jak i regionalnym ${ }^{16}$. Skuteczność policji została przedstawiona jako odsetek przestępstw wykrytych (stanowiących orzeczenie sądu o zaistnieniu przestępstwa) w ogóle przestępstw stwierdzonych. Największą skuteczność policji w 2016 roku zanotowano w województwie świętokrzyskim. Wskaźnik wykrywalności przestępstw kryminalnych wyniósł $63,23 \%$. Na kolejnych miejscach uplasowało się województwo lubelskie $(62,33 \%)$ i małopolskie $(61,32 \%)$. Najmniejszą skutecznością wykazała się policja w województwie mazowieckim. W 2016 roku spośród wszystkich stwierdzonych przestępstw, wykryto jedynie $43,88 \%$. Średni poziom wykrywalności przestępstw w roku 2016 to 59,60\%. Blisko średniej wartości znalazło się województwo lubuskie oraz podlaskie. Dla tych województw wykrywalność jest na poziomie wynoszącym odpowiednio: 59,98\% i 59,77\%. W porównaniu do 2010 roku,

\footnotetext{
${ }^{15}$ A. Mantaj, A. Ostromęcki, D. Zając, Czynniki ksztattujące migracje... op. cit., s. 80-94.

${ }^{16}$ J. Cheda, Rola Europejskiego Urzędu Policji (Europolu) w zapewnieniu bezpieczeństwa wewnętrznego Unii Europejskiej, Rocznik Polityczny Homo Politicus, nr 10/2015, 2015, s. 11-13.
} 
największym postępem $\mathrm{w}$ zakresie skuteczności działania policji wykazało się województwo podlaskie, odsetek ten wzrósł o $14,5 \%$. Spadek o ponad $10 \%$ odnotowano natomiast $\mathrm{w}$ województwie pomorskim.

Niedostateczny dostęp do terenów zielonych na terenach miast może mieć negatywny wpływ zarówno na samopoczucie mieszkańców, jak i na poziom zanieczyszczeń. Niemałe znaczenie ma także rosnąca świadomość ekologiczna i chęć obcowania z naturą blisko miejsca zamieszkania ${ }^{17}$. Największy udział terenów zielonych $(0,74 \%)$ występuje w województwie śląskim. Jest to związane ze zlokalizowanymi w tym województwie licznymi kopalniami, które przyczyniają się do wysokiego zanieczyszczenia powietrza. Wysoki udział zieleni ma za zadanie przede wszystkim oczyszczać powietrze z zanieczyszczeń. Ponadto najbardziej zielonymi województwami są województwa: dolnośląskie $(0,3 \%)$ i małopolskie $(0,25 \%)$. Najmniejszy udział zieleni $\mathrm{w}$ terenach osiedlowych występuje w województwach: podlaskim $(0,06 \%)$, warmińskomazurskim $(0,08 \%)$ oraz świętokrzyskim $(0,1 \%)$. Średnio udział ten wynosi $0,21 \%$. W połowie spośród wszystkich województw udział ten jest równy $0,19 \%$ lub większy. Analizując zmiany, które nastapiły od 2010 roku - spadek udziału zieleni wystapił w trzech województwach: warmińsko-mazurskim, opolskim oraz niewielki w łódzkim. W przypadku województwa warmińsko-mazurskiego - był to spadek o ponad $23 \%$. Największy wzrost natomiast zaobserwowano w województwie lubuskim (blisko o $32 \%)$.

Aktywność inwestycyjna podmiotów gospodarczych jest regulatorem rynku pracy, gdyż istotnie wpływa na popyt na pracę. Wyższa wartość inwestycji w regionie stwarza szansę na powstanie nowych miejsc pracy. Dzięki temu wzrasta zainteresowanie regionem nie tylko ze strony samych migrujących, ale również kolejnych potencjalnych inwestorów, którzy mogą stworzyć kolejne miejsca pracy ${ }^{18}$. Średnia wartość nakładów inwestycyjnych w Polsce w przeliczeniu na jednego mieszkańca w 2016 roku wyniosła blisko $5813 \mathrm{zł}$. W połowie województw wartość ta wyniosła 5501,50 zł lub więcej. Najwyższa wartość inwestycji na jednego mieszkańca wystapiła w województwie mazowieckim i wyniosła 10533 zł. Najniższy poziom inwestycji w przeliczeniu na mieszkańca zanotowano w województwie świętokrzyskim (3605 zł). Niewiele większa wartość inwestycji przypada na mieszkańca województwa lubelskiego i wynosi odpowiednio 3517 zł. W porównaniu do 2010 roku, w siedmiu województwach nastąpił spadek wartości inwestycji w przeliczeniu na mieszkańca. W przypadku województwa świętokrzyskiego spadek ten wyniósł ponad 33\%. Największą dynamiką wzrostu wykazało się województwo opolskie, wzrost ten wyniósł blisko $81 \%$.

Wysokość wynagrodzenia jest jednym z najważniejszych czynników wpływających na jakość życia. Choć odchodzi się od czysto materialnego ujęcia jakości życia, to jednak nie ulega wątpliwości, że zasobność portfela ma duży wpływ na zadowolenie z życia i miejsca pracy. Bieżące zarobki determinują możliwość zaspokajania podstawowych potrzeb oraz potrzeb wyższego rzędu. Przyjmuje się, iż większe zarobki

\footnotetext{
${ }^{17} \mathrm{H}$. Michniewicz-Ankiersztajn, Rola zieleni $w$ ksztaltowaniu przestrzeni miast europejskich $w$ kontekście jakości życia ich mieszkańców, Uniwersytet Kazimierza Wielkiego w Bydgoszczy, Bydgoszcz 2014, s. 130140.

${ }^{18}$ W. Pryjmak, O. Gołubnyk, Zarzqdzanie migracjq..., op. cit., s. 361.
} 
przekładają się na wyższy poziom jakości życia ${ }^{19}$. Można zatem stwierdzić, iż województwa stwarzające możliwości na uzyskanie wyższych zarobków są bardziej atrakcyjne. Średnie wynagrodzenie w 2016 roku wyniosło 3993,79 zł. Najbliżej tej wartości znalazła się średnia płaca w województwie małopolskim i zachodniopomorskim. Jest to odpowiednio 4077,91 zł i 3946,28zł. Najwięcej zarabia się w województwie mazowiecki - średnio 5240,86 zł. Najniższą średnią pensję otrzymują mieszkańcy województwa warmińsko-mazurskiego: 3619,16 zł. We wszystkich województwach zaobserwowano od 2010 roku wzrost średnich płac o ponad 20\%. Najbardziej wynagrodzenia wzrosły w województwie małopolskim - o ponad $28 \%$ (z 3169,90 zł w 2010 roku do 4077,91 zł w 2016 roku). Najniższą natomiast dynamikę zmiany poziomu wynagrodzeń zarejestrowano w województwie śląskim, był to wzrost o blisko 22\% (z 3528,19 zł w 2010 roku do 4295,29 zł). Niezależnie od tego, i tak Ślązacy zarabiają lepiej niż mieszkańcy wielu innych województw.

Bezrobocie jest uważane za jeden z najistotniejszych wskaźników obrazujących sytuację panującą na rynku pracy. Wysoki odsetek osób bezrobotnych niewątpliwie wpływa negatywnie na postrzeganie regionu. Należy przyjąć, że województwa, o niskim udziale osób bezrobotnych wśród osób w wieku produkcyjnym powinny się również charakteryzować wysokim wskaźnikiem miejsc pracy w relacji do osób aktywnych zawodowo $^{20}$. Najmniejszy udział osób bezrobotnych w 2016 roku zaobserwowano w województwie wielkopolskim. Spośród 1000 osób w wieku produkcyjnym, jedynie 36 pozostawało bez pracy. Natomiast, najwięcej, bo aż 81 osób bezrobotnych przypadało na 1000 osób w wieku produkcyjnym w województwie warmińsko-mazurskim. Przeciętnie, w województwach w Polsce w roku 2016, na 1000 osób w wieku produkcyjnym przypadało blisko 6 bezrobotnych. Najbardziej zbliżoną wartość do średniej osiagnęło województwo łódzkie. Porównując rok 2016 z 2010, we wszystkich województwach odnotowano znaczący spadek udziału bezrobotnych w populacji osób w wieku produkcyjnym, a największy w województwie lubuskim. Jednocześnie w sześciu województwach spadek udziału bezrobotnych przekroczył 30\%. Były to województwa: dolnośląskie, lubuskie, małopolskie, pomorskie, wielkopolskie i zachodniopomorskie.

Kwestia jakości powietrza jest ściśle powiązana ze stanem zdrowia mieszkańców, gdyż wysoki poziom zanieczyszczenia powietrza wpływa niekorzystnie np. na układ oddechowy organizmu. Mieszkańcy obszarów silniej zanieczyszczonych mają większą skłonność do zapadania np. na astmę, nowotwory lub choroby krążenia. Wysoce prawdopodobne jest to, iż moda na migrację na tereny wiejskie jest powiązana z większą świadomością ekologiczną, a także dbałością o zdrowie ${ }^{21}$. Średnia emisja zanieczyszczeń pyłowych w Polsce wynosi $0,141 \mathrm{t} / \mathrm{km}^{2} \mathrm{w}$ ciągu roku. W województwie małopolskim i opolskim są to wartości zbliżone do średniej i wynoszą odpowiednio 0,136 oraz $0,134 \mathrm{t} / \mathrm{km}^{2}$. W połowie spośród wszystkich województw wartość ta wynosi $0,11 \mathrm{t} / \mathrm{km}^{2}$ lub więcej. Warto jednak wspomnieć, iż w województwie śląskim wynosi $0,74 \mathrm{t} / \mathrm{km}^{2}$, co znacząco wpływa na średnią ogólnokrajową. W pozostałych województwach bowiem są to wartości z przedziału od 0,034 (woj. warmińsko-

${ }^{19}$ D. Kałuża, Migracje wewnętrzne a poziom rozwoju społeczno-gospodarczego wybranych największych miast $w$ Polsce, Acta Universitatis Lodziensis. Folia Oeconomica, nr 237, 2010, s. 30-32.

${ }^{20}$ W. Janicki, A. Kubik-Komar, Determinanty międzyregionalnych migracji ludności na obszarze Unii Europejskiej w latach 1986-1994, Studia Demograficzne, nr 1(151), 2007, s. 111-136.

${ }^{21}$ L. Kłos, Uwarunkowania ekomigracji w Polsce, Optimum. Studia Ekonomiczne, nr 1(85), 2017, s. 140-141. 
mazurskie) do $0,164 \mathrm{t} / \mathrm{km}^{2}$ (woj. wielkopolskie). Analizując zmiany od $2010 \mathrm{roku}, \mathrm{w}$ całym kraju zaobserwowano zmniejszenie emisji zanieczyszczeń pyłowych. Spadki te wahają się od ponad $12 \%$ do ponad $54 \%$. Największy postęp w redukcji zanieczyszczeń (o 54,19\%) osiagnęło województwo kujawsko-pomorskie, najmniejszy natomiast wielkopolskie (o 12,62\%). Ze względu na dużą emisję warto wspomnieć także o województwie śląskim, w którym to udało się zmniejszyć poziom wskaźnika o blisko $32 \%$.

\section{Ranking województw w oparciu w wskaźnik jakości życia}

Wykorzystana w artykule metoda badawcza może być zakwalifikowana do metod bezwzorcowych ${ }^{22}$, w których syntetyczny miernik agregatowy oblicza się wykorzystując jedynie znormalizowane wartości cech pochodzących ze zbioru wejściowego (początkowego). Dodatkowo, zmienne poddawane są procesowi transformacji. W tym miejscu, następuje określenie kierunku oddziaływania zmiennych wejściowych na zmienną syntetyczną oraz przekształcenie destymulant w stymulanty. Możliwe jest również przypisane wag poszczególnym zmiennych, które zostały zawarte $\mathrm{w}$ zbiorze wejściowym. W tym celu, jako funkcje agregujące, wykorzystywane są średnie: arytmetyczna, harmoniczna lub geometryczna ${ }^{23}$.

W oparciu o dane pochodzące z Banku Danych Lokalnych Głównego Urzędu Statystycznego oraz statystyk policyjnych podjęto próbę konstrukcji syntetycznego wskaźnika jakości życia. Postępowanie badawcze została zrealizowane w następujących krokach.

$\mathrm{Na}$ potrzeby oceny jakości życia $\mathrm{w}$ poszczególnych województwach w Polsce dokonano obliczenia wskaźnika jakości życia bazując na metodologii zaproponowanej przez T. Panka (2015, s. 54), gdzie podstawę konstrukcji miernika syntetycznego stanowi formuła, zapisana wzorem ${ }^{24}$ :

$$
H_{j}=\sum_{i=1}^{9} w_{i} * H_{i j}
$$

gdzie:

$w_{i}$ - wagi poszczególnych czynników,

$H_{i j}$ - wystandaryzowana $i$-ta zmienna dla $j$-tego województwa,

$i=1,2, \ldots, 9-$ numer zmiennej

$j=1,2, \ldots, 16-$ numer województwa

przy czym:

$$
\sum_{i=1}^{9} w_{i}=1
$$

\footnotetext{
${ }^{22}$ Z. Binderman, B. Borkowski, W. Szczesny, O pewnych metodach porzqdkowania i grupowania w analizie zróżnicowania rolnictwa, Roczniki Nauk Rolniczych, Seria G, T. 96, z. 2, 2009, s. 78, http://sj.wne.sggw.pl/pdf/RNR_2009_n2_s77.pdf.

${ }_{23}$ T. Grabiński, Wielowymiarowa analiza porównawcza w badaniach dynamiki zjawisk ekonomicznych, Zeszyty Naukowe AE w Krakowie. Seria specjalna, Monografie, nr 61, 1984.

${ }^{24}$ T. Panek, Jakość życia gospodarstw domowych w Polsce $w$ uktadzie województw, Zeszyty Naukowe Instytut Statystyki i Demografii SGH, Nr 46/2015, Warszawa.
} 
W artykule wagi poszczególnych zmiennych zostały wyznaczone w oparciu o metodę współczynników korelacji cząstkowych, podaną wzorem:

$$
w_{i}=\frac{\sum_{\substack{i=1 \\ i^{\prime} \neq i}}^{9} r_{i, i^{\prime}}^{2}}{\sum_{i=1}^{9} \Sigma_{i^{\prime}}^{9} r_{i . i^{\prime}}^{2}}
$$

gdzie:

$r_{i, i^{\prime}}^{2}-$ kwadrat współczynnika korelacji cząstkowej $i$ - tego wskaźnika z $i^{\prime}-$ tym wskaźnikiem.

W artykule zaproponowany wejściowy zbiór zmiennych diagnostycznych jest dziewięcioelementowy. Można zatem przyjąć, że każda z nich opisuje inną dziedzinę jakości życia, a wyodrębnianie poddomen (sub-agregatów) jakości życia nie jest zasadne. W związku z tym współczynniki korelacji cząstkowych są obliczane pomiędzy wartościami kolejnych wskaźników indywidualnych dla poszczególnych województw w Polsce.

W kolejnym kroku dokonano ustalenia wag poszczególnych zmiennych za pomocą metody korelacji cząstkowej. Wartości wag dla poszczególnych zmiennych przedstawia Tabela 3.

Tabela 3. Wagi zmiennych uwzględnionych we wskaźniku jakości życia

\begin{tabular}{|l|c|c|}
\hline Zmienna & $\mathbf{2 0 1 0}$ & $\mathbf{2 0 1 6}$ \\
\hline Gęstość zaludnienia (os./km²) & 0,145 & 0,114 \\
\hline Udział parków, zieleńców i terenów zieleni osiedlowej w powierzchni ogółem (\%) & 0,144 & 0,122 \\
\hline Średnie wynagrodzenie brutto (zł) & 0,139 & 0,148 \\
\hline Emisja zanieczyszczeń pyłowych na $1 \mathrm{~km}^{2}$ & 0,131 & 0,103 \\
\hline Udział liczby bezrobotnych w liczbie osób w wieku produkcyjnym (\%) & 0,109 & 0,096 \\
\hline Powierzchnia mieszkań oddanych do użytku w m² na jednego mieszkańca (m²/os.) & 0,094 & 0,072 \\
\hline $\begin{array}{l}\text { Liczba zarejestrowanych podmiotów gospodarczych w przeliczeniu na 1000 } \\
\text { mieszkańców }\end{array}$ & 0,092 & 0,123 \\
\hline Nakłady inwestycyjne na jednego mieszkańca (zł) & 0,080 & 0,131 \\
\hline Wskaźnik wykrywalności przestępstw kryminalnych (\%) & 0,066 & 0,092 \\
\hline
\end{tabular}

Źródlo: opracowanie własne na podstawie Banku Danych Lokalnych - www.stat.gov.pl oraz statystyk policyjnych.

Wagi dla poszczególnych zmiennych otrzymywane są w oparciu o macierz korelacji cząstkowej. Oznacza to, iż jeśli dana zmienna jest wysoce skorelowana z innymi - uzyskuje tym samym wyższą wagę, a zatem ma większy wpływ na wartość wskaźnika jakości życia. Otrzymane wyniki w Tabeli 3 wynikają ze wzajemnego skorelowania poszczególnych zmiennych. W przypadku wysokiej korelacji pomiędzy zmiennymi można oczekiwać, iż zmienna przyjmie wysoką wagę. Najwyższą wagę $\mathrm{w}$ 2010 roku uzyskała zmienna dotycząca średniej gęstości zaludnienia. Zawdzięcza to wysokiemu skorelowaniu między innymi: z udziałem osób bezrobotnych wśród osób w wieku 15-64 lata, emisją zanieczyszczeń pyłowych w ciągu roku w przeliczeniu na 1 
$\mathrm{km}^{2}$ oraz udziałowi powierzchni zielonej na terenach osiedlowych. Dla roku 2016 najbardziej wpływową zmienną okazało się średnie wynagrodzenie brutto, które wykazało silną korelację $\mathrm{z}$ inwestycjami przypadającymi na jednego mieszkańca, skutecznością policji oraz z liczbą zarejestrowanych podmiotów gospodarczych w przeliczeniu na 1000 mieszkańców. Najniższymi wagami w roku 2010 i 2016 były odpowiednio wskaźnik wykrywalności przestępstw kryminalnych oraz powierzchnia mieszkań oddanych do użytku $\mathrm{w}^{2}{ }^{2} \mathrm{w}$ przeliczeniu na jednego mieszkańca.

Zmienna $\mathrm{H}_{i j}$ przed podstawieniem do wzoru na sumaryczny wskaźnik jakości życia została poddana normalizacji $\mathrm{W}$ tym miejscu wykorzystano metodę unitaryzacji $\mathrm{z}$ rozstępem wartości zmiennej jako punktem odniesienia ${ }^{25}$. Polega ona na uzyskaniu zmiennych o ujednoliconym zakresie zmienności na podstawie różnicy pomiędzy ich wartościami maksymalnymi i minimalnymi (ujęcie klasyczne) lub maksimum $\mathrm{z}$ medianowych odchyleń bezwzględnych w ujęciu pozycyjnym, równym stale 1 (ujęcie pozycyjne). Formuła na unitaryzację klasyczną opisana jest wzorem ${ }^{26}$ :

$$
\begin{aligned}
& \text { Dla stymulant: } H_{i j}=\frac{X_{i j}-\min _{j}\left\{X_{i j}\right\}}{\max _{j}\left\{X_{i j}\right\}-\min _{j}\left\{X_{i j}\right\}} \\
& \text { Dla destymulant: } H_{i j}=\frac{X_{i j}-\min _{j}\left\{X_{i j}\right\}}{\min _{j}\left\{X_{i j}\right\}-\max _{j}\left\{X_{i j}\right\}}
\end{aligned}
$$

gdzie:

$\max _{j}\left\{X_{i j}\right\}, \mathrm{i}=1, \ldots, 9, \mathrm{j}=1, \ldots, 16$ - maksimum $i$-tej zmiennej w danym roku,

$\min _{j}\left\{X_{i j}\right\}, \mathrm{i}=1, \ldots, 12, \mathrm{j}=1, \ldots, 16-$ minimum $i$-tej zmiennej w danym roku.

Po standaryzacji oraz obliczeniu wag, można przystapić do obliczenia wskaźnika jakości życia danego wzorem:

gdzie:

$$
H_{j}=\sum_{i}^{9} w_{i} H_{i j}
$$

$\mathrm{w}_{i}$ - wagi dla poszczególnych czynników,

$\mathrm{H}_{i j}-i$-ta zmienna dla j-tego województwa.

Tabela 4 przedstawia wartości wskaźnika jakości życia dla każdego z województw. Zmienne zostały poddane standaryzacji, dzięki czemu wartości wskaźnika jakości życia znajdują się $\mathrm{w}$ przedziale [0;1]. Wyższa wartość jest równoznaczna $\mathrm{z}$ większym poziomem atrakcyjności, natomiast niska wartość oznacza niski poziom jakość życia.

${ }^{25}$ P. Kowalik, Metoda unitaryzacji zerowanej w arkuszach kalkulacyjnych, [w:] Rola informatyki w naukach ekonomicznych i społecznych, (red.) Z.E. Zieliński, Wydawnictwo Wyższej Szkoły Handlowej, Kielce 2011, s. 204-209.

${ }^{26}$ Z. Kukuła, J. Skrzypek, A. Walkosz, Badania operacyjne $w$ przykładach $i$ zdaniach, Wydawnictwo Naukowe PWN, Warszawa 2006, s. 282-283, 288. 
Tabela 4. Wartości wskaźnika jakości życia dla poszczególnych województw

\begin{tabular}{|l|c|c|c|c|c|}
\hline Województwo & $\mathbf{2 0 1 0}$ & $\mathbf{2 0 1 6}$ & Pozycja 2010 & Pozycja 2016 & Zmiana \\
\hline Dolnośląskie & 0,513 & 0,550 & 4 & 3 & +1 \\
\hline Kujawsko-pomorskie & 0,275 & 0,275 & 14 & 12 & +2 \\
\hline Lubelskie & 0,295 & 0,267 & 11 & 13 & -2 \\
\hline Lubuskie & 0,416 & 0,390 & 7 & 9 & -2 \\
\hline Łódzkie & 0,361 & 0,336 & 10 & 10 & 0 \\
\hline Małopolskie & 0,491 & 0,529 & 6 & 4 & +2 \\
\hline Mazowieckie & 0,674 & 0,674 & 1 & 1 & 0 \\
\hline Opolskie & 0,384 & 0,410 & 9 & 7 & +2 \\
\hline Podkarpackie & 0,263 & 0,259 & 15 & 14 & +1 \\
\hline Podlaskie & 0,282 & 0,287 & 12 & 11 & +1 \\
\hline Pomorskie & 0,530 & 0,517 & 3 & 5 & -2 \\
\hline Śląskie & 0,574 & 0,554 & 2 & 2 & 0 \\
\hline Świętokrzyskie & 0,276 & 0,248 & 13 & 15 & -2 \\
\hline Warmińsko-mazurskie & 0,258 & 0,224 & 16 & 16 & 0 \\
\hline Wielkopolskie & 0,513 & 0,511 & 5 & 6 & -1 \\
\hline Zachodniopomorskie & 0,388 & 0,403 & 8 & 8 & 0 \\
\hline
\end{tabular}

Źródlo: opracowanie własne na podstawie Banku Danych Lokalnych - www.stat.gov.pl oraz statystyk policyjnych.

Zarówno w roku 2010, jak i 2016 najwyższą wartością wskaźnika jakości życia charakteryzuje się województwo mazowieckie. Wynika to z faktu, iż: na 1000 mieszkańców przypada tam najwięcej podmiotów gospodarczych, na jednego mieszkańca przypada największa powierzchnia mieszkań oddanych do użytku oraz największa wartość nakładów inwestycyjnych. Ponadto, występują tam najwyższe średnie wynagrodzenia brutto.

$\mathrm{W}$ obu porównywanych jednostkach czasu swoją pozycję w rankingu utrzymały jeszcze cztery województwa: śląskie (miejsce 2), zachodniopomorskie (miejsce 8), łódzkie (miejsce 10) oraz warmińsko-mazurskie. Ostatnie z wymienionych województw zajęło w rankingu ostatnie miejsce, zarówno w roku 2010 jak i 2016. Najniższą pozycję województwa warmińsko-mazurskiego w rankingu wyjaśnia między innymi najwyższy odsetek osób pozostających bez pracy. Mając na uwadze, że zmienna ta ma negatywny wpływ na badane zjawisko, najbardziej pożądane są niskie jej wartości. Słaba pozycja województwa warmińsko-mazurskiego była również w pewnym stopniu wynikiem niskiego poziomu wskaźnika - gęstość zaludnienia. Również średnie wynagrodzenie brutto jest tutaj najniższe spośród wszystkich województw. Na korzyść jednak działa niska emisja zanieczyszczeń pyłowych w ciagu roku przypadająca na $1 \mathrm{~km}^{2}$.

Sześć województw poprawiło swoją pozycję w rankingu w 2016 roku w porównaniu do roku 2010. W trzech spośród nich była to poprawa o więcej niż jedno miejsce. Są to województwa: kujawsko-pomorskie (z 14. miejsca na 12.), małopolskie (z 6. miejsca na 4.) oraz opolskie (z 9. miejsca na 7.). Pięć województw odnotowało spadki w rankingu jakości życia, z czego w czterech był to spadek o dwa miejsca. Są to 
województwa: lubelskie ( z miejsca 11. na 13.), lubuskie (z miejsca 7. na 9.), pomorskie (z miejsca 3. a 5.) oraz świętokrzyskie ( z miejsca 13. na 15.). Jedynym województwem, które spadło w rankingu o jedną pozycję, było województwo wielkopolskie, które w 2016 roku zajęło 6. miejsce.

\section{Podsumowanie}

Wybrany zestaw zmiennych wydaje się być stabilny w czasie. Przeprowadzenie analizy porównawczej dla roku 2010 oraz 2016 nie wykazało znaczących różnic w rankingach województw ze względu na poziom jakości życia. Co więcej, zarówno w roku 2016 jak i 2010 ścisła czołówka województw była taka sama, pierwsze miejsce zajmowało województwo mazowieckie, a drugie - województwo śląskie. Poszczególne obiekty przesuwały się w rankingu o co najwyżej dwa miejsca. Przy czym aż 5 spośród województw utrzymało swoją pozycję. Daje to podstawę aby sądzić, że wybrane zmienne można uznać, za kluczowych reprezentantów poszczególnych kategorii opisujących jakość życia.

Podsumowując, uzyskane wyniki badań potwierdziły wcześniejsze przypuszczenia, że najwyżej w rankingu jakości życia znajdzie się województwo mazowieckiego, do którego jednak trzeba podchodzić z największą ostrożnością. Wpływ na wartości wskaźników indywidualnych w województwie mazowieckim w dużej mierze wywiera sytuacja społeczna i gospodarcza stolicy. Dlatego pomiar jednocechowy jest w dużej mierze odzwierciedleniem wartości charakterystycznych dla Warszawy, aniżeli dla całego województwa. Z badań geopolitycznych oraz ekonomicznych wynika, że warunki panujące w stolicy państwa zawsze znacznie odbiegają od tych występujących nawet na obszarach znajdujących się $w$ bezpośrednim sąsiedztwie stolicy. Nie ulega jednak wątpliwości, że utrzymanie pierwszej pozycji w rankingu jakości życia województwo mazowieckie zawdzięcza przede wszystkim najwyższej dynamice wzrostu liczby podmiotów gospodarczych, ponad 18-procentowemu spadkowi odsetka osób bezrobotnych $\mathrm{w}$ grupie osób w wieku produkcyjnym, oraz znacznemu spadkowi zanieczyszczenia powietrza. Podobnie województwa, które przesunęły się w górę rankingu, awans zawdzięczają w dużej mierze znacznym spadkom odetka osób bezrobotnych oraz poprawie warunków bezpieczeństwa wyrażonych wskaźnikiem wykrywalności przestępstw. W przypadku województwa małopolskiego ważnym czynnikiem, który zdecydował o pozycji województwa w rankingu jakości życia w 2016 była sytuacja na rynku mieszkaniowym i znaczący wzrost powierzchni mieszkań oddanych do użytku.

W artykule ukazano jakość życia w możliwie najwęższym ujęciu, przy jednoczesnym ukazaniu wielowymiarowości i wieloaspektowości tego zjawiska. Satysfakcjonujący jest fakt, przypisania tylko jednego reprezentanta uznanego za kluczowego każdej z dziewięciu wyodrębnionych głównych kategorii opisujących jakość życia. Warto jeszcze zwrócić uwagę, na różnice jakie wystapiły w systemie ważenia cech w roku 2016 względem roku 2010. W przypadku prowadzenia analiz dla różnych punktów czasowych warto rozpatrywać w przyszłości rozwiązania, które umożliwią utrzymanie zbieżnych wag. Zwłaszcza, że w przypadku metod bezwzorcowych to wagi przypisane poszczególnym zmiennym w największym stopniu decydują o porządkowaniu liniowym obiektów. Uzyskane wyniki mogą stanowić 
wartościowe źródło informacji dla decydentów politycznych, praktyków gospodarczych oraz działaczy społecznych na temat poziomu jakości życia w poszczególnych województwach w Polsce.

\section{Bibliografia}

Binderman Z., Borkowski B., Szczesny W., O pewnych metodach porzqdkowania i grupowania w analizie zróżnicowania rolnictwa, Roczniki Nauk Rolniczych, Seria G, T. 96, z. 2, 2009, s. 78, http://sj.wne.sggw.pl/pdf/RNR_2009_n2_s77.pdf.

Bywalec Cz., Rudnicki L., Podstawy teorii i metodyki badań konsumpcji, Akademia Ekonomiczna w Krakowie, Kraków 1992.

Cheda J., Rola Europejskiego Urzędu Policji (Europolu) $w$ zapewnieniu bezpieczeństwa wewnętrznego Unii Europejskiej, Rocznik Polityczny Homo Politicus, nr 10/2015, 2015, s. 11-13. Grabiński T., Wielowymiarowa analiza porównawcza $w$ badaniach dynamiki zjawisk ekonomicznych, Zeszyty Naukowe AE w Krakowie. Seria specjalna, Monografie, nr 61, 1984.

Janicki W., Kubik-Komar A., Determinanty międzyregionalnych migracji ludności na obszarze Unii Europejskiej w latach 1986-1994, Studia Demograficzne, nr 1(151), 2007, s. 111-136.

Jankowska E., Pojęcie i narzędzia pomiaru jakości życia, Toruńskie Studia Międzynarodowe nr 1(4), Toruń 2011, s. 34-37.

Kałuża D., Migracje wewnętrzne a poziom rozwoju społeczno-gospodarczego wybranych największych miast w Polsce, Acta Universitatis Lodziensis. Folia Oeconomica, nr 237, 2010, s.30-32.

Kłos L., Uwarunkowania ekomigracji w Polsce, Optimum. Studia Ekonomiczne, nr 1(85), 2017, s. 140-141.

Kordos J., Metodologia i wykorzystanie wskaźników społecznych, Wiadomości Statystyczne, nr 12, 1990.

Kowalik P., Metoda unitaryzacji zerowanej w arkuszach kalkulacyjnych, [w:] Z.E. Zieliński (red.), Rola informatyki $w$ naukach ekonomicznych $i$ społecznych, Wydawnictwo Wyższej Szkoły Handlowej, Kielce 2011, s. 204-209.

Kukuła Z., Skrzypek J., Walkosz A., Badania operacyjne $w$ przykładach $i$ zdaniach, Wydawnictwo Naukowe PWN, Warszawa 2006, s. 282-283, 288.

Kurzawa I., Łuczak A., Wysocki F., Zastosowanie metod taksonomicznych i ekonometrycznych w wielowymiarowej analizie poziomu życia mieszkańców powiatów w Polsce, [w:] Prace naukowe Uniwersytetu Ekonomicznego we Wrocławiu, Taksonomia 28. Klasyfikacja i analiza danych teoria i zastosowania, Wyd. Uniwersytetu Ekonomicznego we Wrocławiu, Wrocław 2017, s. 130. A. Luszniewicz, Statystyka społeczna. Podstawowe problemy i metody, PWE, Warszawa 1982.

Mantaj A., Ostromęcki A., Zając D., Czynniki ksztattujace migracje ludności w gminach wiejskich Polski Wschodniej, Wiadomości Statystyczne, nr 11(678), 2017, s. 74-85.

Michniewicz-Ankiersztajn H., Rola zieleni $w$ ksztaltowaniu przestrzeni miast europejskich $w$ kontekście jakości życia ich mieszkańców, Uniwersytet Kazimierza Wielkiego w Bydgoszczy, Bydgoszcz 2014, s. 130-140.

Miler-Zawodniak A., Teorie potrzeb jako współczesne teorie motywacji, Obronność - Zeszyty Naukowe Wydziału Zarządzania i Dowodzenia Akademii Obrony Narodowej nr 4, 2012, s. 101116.

Nations Unies, Rapport sur la definition et evaluation des niveaux de vie du point de vue international (Report on the identification and assessment of living standards as an economic indicator internationally), New York 1954.

Owsiński J., Trachalski T., Współczesne Problemy Zarzqdzania. Pomiar jakości życia. Uwagi na marginesie pewnego rankingu, Instytut Badań Systemowych PAN, Warszawa 2008, s. 61-67

Panek T., Jakość życia gospodarstw domowych $w$ Polsce $w$ układzie województw, Zeszyty Naukowe - Instytut Statystyki i Demografii SGH, Nr 46/2015, Warszawa. 
Piasny J., Poziom i jakość życia ludności oraz źródła i mierniki ich określania, Ruch Prawniczy, Ekonomiczny i Socjologiczny, Rok LV, Zeszyt 2, 1993.

Pryjmak W., Gołubnyk O., Zarzqdzanie migracja ludności poprzez wpływ na czynniki społecznogospodarcze, „Zeszyty Naukowe WSOWL, nr 4 (162), 2011, s. 361.

Rutkowski J., Jakość Życia - Koncepcja i projekt badania, ZBSE, Warszawa 1987, s. 7-10.

Sompolska-Rzechuła A., Jakość życia jako kategoria ekonomiczna, Folia Pomeranae Universitatis Technologiae Stetinensis, Oeconomica, nr 301 (71), 2013.

Słaby T., Poziom i jakość życia [w:] T. Panek, A. Szulc (red.), Statystyka Społeczna. Wybrane zagadnienia, SGH w Warszawie, Oficyna Wydawnicza, Warszawa 2007.

Sztaur-Jaworska B., Diagnoza i diagnozowanie w polityce społecznej, [w:] G. Firlit-Fesnak, M. Szylko-Skoczny (red.), Polityka społeczna, PWN, Warszawa 2009.

Szukiełojć-Bieńkuńska A., Walczak T., Statystyczny pomiar postępu społeczno-gospodarczego w zmieniajacym się świecie, Wiadomości Statystyczne, nr 7/8 (602/603), 2011, s. 9-29.

\section{Summary}

Quality of life is expressed not only through the consumption of material goods and services but above all by the ability to meet needs related to, for example, the state of the natural environment, the type and form of interpersonal relationships, dignity and respect for human rights, as well as the quantity and quality of free time and self-fulfilment. An extensive range of issues and phenomena that remain in direct relation to quality of life means that its measurement is a difficult problem and arouses the unflagging interest of researchers. The aim of the paper is a multivariate assessment of the quality of life in Poland's voivodships, including a detailed discussion of univariate measurements and changes over time. The conducted analyses indicate that the selected set of variables is characterised by relative stability over time. The ranking of the voivodships in 2016 did not differ significantly from the ranking prepared for 2010. This gives grounds to believe that the selected variables can be considered as key representatives of individual categories describing quality of life.

Keywords: quality of life, linear ordering, differentiation, method of partial correlation coefficients

Informacja o autorach

dr Elżbieta Roszko-Wójtowicz

Katedra Statystyki Ekonomicznej i Społecznej

Uniwersytet Łódzki

e-mail: eroszko33@gmail.com

ORCID: 0000-0001-9337-7218

dr hab. Maria Grzelak, prof. U⿺

Katedra Statystyki Ekonomicznej i Społecznej

Uniwersytet Łódzki

e-mail: maria.grzelak@uni.lodz.pl

ORCID: 0000-0003-4353-9893 